\title{
Sub-chronic Effect of Methanol-Dichloromethane Stem Bark Extract of Stemonocoleus micranthus Harms. (Fabaceae) on Lipid Profile and Histology of Liver and Kidney of Rats
}

Florence N Mbaoji, Adaobi C Ezike, Chukwuemeka S Nworu, Collins A Onyeto, Bonaventure C Obi, Theophine C Akunne, Chiamaka Okoli, Cynthia Okpalaeke and Peter A Akah

Department of pharmacology and toxicology, Faculty of pharmaceutical sciences, University of Nigeria, Nsukka, PMB 410001, Enugu state, Nigeria

*Corresponding author: Bonaventure Obi, Department of pharmacology and toxicology, Faculty of pharmaceutical sciences, University of Nigeria, Nsukka, PMB 410001, Enugu state, Nigeria, Tel: +2348035704228; E-mail: bonaventure.obi@unn.edu.ng

Received date: Aug 14, 2017; Accepted date: Sep 06, 2017; Published date: Sep 08, 2017

Copyright: (C) 2017 Mbaoji F, et al. This is an open-access article distributed under the terms of the Creative Commons Attribution License, which permits unrestricted use, distribution, and reproduction in any medium, provided the original author and source are credited.

\begin{abstract}
In Nigerian ethnomedicine, Stemonocoleus micranthus Harms (Fabaceae) is used in the management of heart related diseases. This study investigated the effect of sub-chronic administration of methanol-dichloromethane stem bark extract of S. micranthus (SME) on lipid profile and histology of liver and kidney of rats. Adult albino rats of both sexes were randomly divided into four groups $(n=5)$ and received daily administration of SME $(100,200$, and 400 $\mathrm{mg} / \mathrm{kg}$ ) and $2 \mathrm{ml} / \mathrm{kg}$ distilled water (control) respectively for 28 days per oral. Biochemical tests were performed pretreatment and subsequently fortnightly as the treatment commenced. The results showed that the extract increased the serum high density lipoprotein cholesterol concentration while low density lipoprotein cholesterol, total cholesterol, triacylglycerol, and very low density lipoprotein cholesterol concentrations were reduced compared with the baseline values. However, the histopathological examination of the liver and kidney of the rats that received extract and solvent revealed normal portal area with bile ducts and hepatic artery as well as normal glomerulus and renal tubules without observable changes suggesting zero tendency of causing toxic effects. The preliminary phytochemical analysis showed that SME contained alkaloids, glycosides, flavonoids, reducing sugars, terpenoids, saponins, proteins and, fats oils. SME exhibited an oral $\mathrm{LD}_{50}>5 \mathrm{~g} / \mathrm{kg}$ in mice. These findings suggest that the stem bark extract of $S$. micranthus contains constituents that possess hypolipidemic activity in rats.
\end{abstract}

Keywords: Stemonocoleus micranthus extract (SME); Phytochemical screening; Lipid profile; Histopathology

\section{Introduction}

Atherosclerosis and coronary heart disease are the major health problems affecting both developed and developing countries [1,2]. Alterations in lipid metabolism may predispose to high levels of lipid in the system. Excessive storage of lipid causes cellular and tissue damage in the brain, peripheral nervous system, liver, spleen and bone marrow [3]. Many studies have shown that elevated concentration of low density lipoprotein (LDL) cholesterol and reduced high density lipoprotein (HDL) cholesterol level are powerful risk factors for atherosclerosis and coronary heart disease [4], whereas high concentration of high density lipoprotein (HDL) cholesterol or a low LDL to HDL cholesterol ratio may protect against coronary heart disease $[5,6]$.

The use of herbs as medicine has played an important role in nearly every culture on earth [7]. Herbal medicine is based on the premise that plants contain natural substances that can promote health and alleviate illness. In Nigeria, herbal medicine is fast emerging as an alternative treatment for a wide range of ailments possibly, due to their lower costs, availability, fewer adverse effects and perceived effectiveness. Several Herbal extracts are often used to reduce high blood cholesterol concentrations; provide some protection against heart related diseases.

Stemonocoleus micranthus Harms (Fabaceae) is one of the wild African plants used for medicinal purposes. The plant is an ever green tree endemic in West and Central Africa. The morphological characteristics of the plant have been described [8]. A bark decoction of the plant is used as treatment for a wide range of ailments including rheumatism, infertility in women, diarrhoea and dysentery, ulcers, hypertension, pyretic, emetic, helminthic and mental illnesses [8]. Additionally, it is well documented that the plant possessed analgesic, narrow spectrum antibacterial, CNS depression and local anaesthetic properties [9]. It is equally used in relieving pains, treating contaminated wound, enhancing conception and light construction work (non- medicinal uses) [10]. It has also been investigated to possess anti-ulcer [11], and antioxidant/hepatoprotective [12] activities among others. Hence in this study, we investigated the sub-chronic effect of the stem bark extract of Stemonocoleus micranthus Harms. (Fabaceae) on lipid profile and histology of liver and kidney of rats.

\section{Materials and methods}

\section{Preparation of plant material}

Fresh stem barks of Stemonocoleus micranthus were collected from a forest in Orba, Nsukka in April and May, 2016. The identity was established and authenticated at the International Centre for Ethnomedicine Drug Development (Inter-CEDD), Nsukka, Nigeria. The stem bark was carefully separated from the woody part, dried and then pulverized into fine powder. The powdered plant material $(2 \mathrm{~kg})$ was extracted with a 1:1 mixture of Methanol-dichloromethane by continuous extraction in a Soxhlet extractor. The resulting filtrate was concentrated under reduced pressure at a temperature of $40^{\circ} \mathrm{C}$ to obtain S. micranthus extract (SME) (106.28 g). 
Citation: Mbaoji F, Ezike A, Nworu C, Onyeto C, Obi B, et al. (2017) Sub-chronic Effect of Methanol-Dichloromethane Stem Bark Extract of Stemonocoleus micranthus Harms. (Fabaceae) on Lipid Profile and Histology of Liver and Kidney of Rats. J Pharmacogn Nat Prod 3: 138. doi: $10.4172 / 2472-0992.1000138$

Page 2 of 6

\section{Preliminary phytochemical analysis}

The test was carried out based on procedures outlined by Harborne [13]; Trease and Evans [14].

\section{Experimental design}

The study was performed on 20 healthy albino rats (150-200 g) of both sexes. The rats were purchased from the animal house of the Department of Pharmacology and Toxicology, Faculty of Pharmaceutical Sciences, University of Nigeria, Nsukka. All animal experiments were handled in compliance with the National Institute of Health Guidelines for Care and Use of Laboratory Animals (Pub No. 85-23, revised 1985), and in accordance with the University Ethical Committee on the use of Laboratory Animals. The animals were kept in standard laboratory conditions under a $12 \mathrm{~h}$ dark and $12 \mathrm{~h}$ light cycle, at $25^{\circ} \mathrm{C}$, and were provided with a diet and water ad libitum. The rats were randomly divided into 4 groups: $\mathrm{A}, \mathrm{B}, \mathrm{C}$, and $\mathrm{D}, 5$ animals in each group. Groups A, B, C received SME at 100, 200, and $400 \mathrm{mg} / \mathrm{kg}$ BW p.o. once daily for 28 days and group D (control group) received distilled water ( $2 \mathrm{ml} / \mathrm{kg}$ BW p.o.).

\section{Biochemical analysis}

Blood samples were collected through ocular puncture thrice with the aid of non-heparinised capillary tube and transferred into clean sample bottles. The collected blood was allowed to clot and centrifuged at $3000 \mathrm{rpm}$ for $10 \mathrm{~min}$ to obtain the serum component for further biochemical analysis. The blood was collected firstly at the beginning of the experiment (day 0) to assay for basal serum lipid levels. Subsequently, blood samples were recollected from the animals on days 14 and 28 post treatment to re-assay for serum lipid levels. The serum total cholesterol (TC), high-density lipoprotein cholesterol (HDL-C), low-density lipoprotein cholesterol (LDL-C), triacylglycerol (TAG) and very low density lipoprotein cholesterol (VLDL) concentrations were analyzed using the methods of Allain et al. [15], Albers et al. [16], Assman et al. [17]) and, Jacobs and Van Denmark [18] as contained in test kits by Quimica Clinica Aplicada (QCA), Spain.

\section{Histopathological analysis}

At the end of the experimental period, the kidneys and livers were obtained and fixed in $10 \%$ formalin solution for histological examination. The organs were each trimmed, processed, embedded in paraffin wax, sectioned, placed on glass microscope slides, and stained with hematoxylin and eosin (H.E.). The stained slides were viewed under the microscope in oil immersion with magnification of $\times 400$.

\section{Statistical analysis}

Data obtained was analyzed using One-Way ANOVA and further subjected to Duncan post hoc tests and presented as Mean \pm SEM. Differences between means were accepted significant at $\mathrm{p}<0.05$.

\section{Results and discussion}

Hypolipidemic properties have been confirmed in many plant species and plant products in medicinal use $[19,20]$. As a result, there is need for continued search for such plants with hypolipidemic properties as their active phytoconstituents could make tremendous ameliorative impact in global health burden of dyslipidemia. In Nigerian ethnomedicine, documented and undocumented traditional evidence abounds of the use of Stemonocoleus micranthus Harms (Fabaceae) in the management of heart related diseases. The study therefore, investigated the sub-chronic effect of the stem bark extract of Stemonocoleus micranthus in an animal model.

Besides carrying out a qualitative phytochemical analysis of the plant extract, the changes in the lipid profile markers (TC, HDL, LDL, TAG and VLDL) of the different animal groups were observed as part of the design for this study, as well as the histology of the liver and kidney of the different animal groups. In Table 1, The TC concentration was not significantly $(\mathrm{p}>0.05)$ different as compared with the control group. Treatment with $400 \mathrm{mg} / \mathrm{kg}$ SME produced significant $(\mathrm{p}<0.05)$ reduction in the levels of serum TC on day 28 compared with the control group and day 0 values, respectively. However, relative to day 0 values, the changes (\%) observed on days 14 and 28 in TC concentration for SME $(100,200,400 \mathrm{mg} / \mathrm{kg})$ were 29.10, $6.20,15.90 \%$ and $6.90,5.20,24.50 \%$ respectively (Table 1 ).

\begin{tabular}{|c|c|c|c|c|c|c|c|}
\hline Group & Treatment & Dose (mg/kg) & Day 0 & Day 14 & Day 28 & $\begin{array}{l}\text { Change (\%) } \\
\text { (Day 14) }\end{array}$ & $\begin{array}{l}\text { Change (\%) (Day } \\
\text { 28) }\end{array}$ \\
\hline A & SME & 100 & $70.60 \pm 5.37$ & $91.20 \pm 3.68$ & $75.49 \pm 3.66$ & -29.10 & -6.90 \\
\hline B & - & 200 & $80.94 \pm 4.58$ & $85.40 \pm 7.04$ & $76.74 \pm 5.58$ & -6.20 & 5.20 \\
\hline C & - & 400 & $81.42 \pm 5.56$ & $94.39 \pm 5.54$ & $61.48 \pm 4.24^{* \#}$ & -15.90 & 24.50 \\
\hline$D$ & Solvent & - & $84.38 \pm 5.45$ & $84.56 \pm 3.54$ & $80.77 \pm 4.48$ & -0.21 & 4.27 \\
\hline \multicolumn{8}{|c|}{$\begin{array}{l}\text { Values are mean } \pm \mathrm{SEM}, \mathrm{n}=5 \text { per group; * \#: } \mathrm{p}<0.05 \text { compared with control and day } 0 \text { values respectively (One-Way Anova; Duncan test post hoc). SME - } \\
\text { Stemonocoleus micranthus extract, solvent- distilled water. Change }(\%) \text { calculated relative to day } 0 \text { values. }\end{array}$} \\
\hline \multicolumn{8}{|c|}{ able 1: Effect of SME on serum total cholesterol concentration. } \\
\hline Group & Treatment & Dose $(\mathrm{mg} / \mathrm{kg})$ & Day 0 & Day 14 & Day 28 & $\begin{array}{l}\text { Change (\%) (Day } \\
\text { 14) }\end{array}$ & $\begin{array}{l}\text { Change (\%) (Day } \\
\text { 28) }\end{array}$ \\
\hline A & SME & 100 & $30.62 \pm 2.84$ & $46.42 \pm 3.28$ & $49.21 \pm 5.55$ & -34.04 & -37.78 \\
\hline B & - & 200 & $32.88 \pm 2.39$ & $45.60 \pm 2.29$ & $49.47 \pm 5.13$ & -24.17 & -33.54 \\
\hline
\end{tabular}


Citation: Mbaoji F, Ezike A, Nworu C, Onyeto C, Obi B, et al. (2017) Sub-chronic Effect of Methanol-Dichloromethane Stem Bark Extract of Stemonocoleus micranthus Harms. (Fabaceae) on Lipid Profile and Histology of Liver and Kidney of Rats. J Pharmacogn Nat Prod 3: 138. doi: $10.4172 / 2472-0992.1000138$

Page 3 of 6

\begin{tabular}{|l|l|l|l|l|l|l|}
\hline C & - & 400 & $30.79 \pm 4.39$ & $40.79 \pm 3.49$ & $34.81 \pm 4.58$ & -11.55 \\
\hline D & Solvent & - & $32.20 \pm 3.87$ & $40.79 \pm 3.49$ & $51.37 \pm 3.68$ & -32.48 \\
\hline $\begin{array}{l}\text { Values are mean } \pm \text { SEM, n=5 per group; * \#: p<0.05 compared with control and day 0 values respectively (One Way Anova; Duncan test post hoc). SME- } \\
\text { Stemonocoleus micranthus extract, solvent- distilled water. Change (\%) calculated relative to day 0 values. }\end{array}$ \\
\hline
\end{tabular}

Table 2: Effect of SME on serum HDL-cholesterol concentration.

In Tables 1 and 2, the changes in HDL-C and LDL-C of animals treated with the stem bark extract of Stemonocoleus micranthus were compared to those of the control group, as well as the baseline values (Day 0). No significant $(\mathrm{p}>0.05)$ changes occurred in HDL-C and LDL-C measured compared with the control group. However, compared to baseline values, the percentage change in HDL-C was $34.04,24.17,32.48 \%$ and $37.78,33.54,11.55 \%$ while LDL-C was 34.40 , $12.30,16.10 \%$ and $14.70,29.90,36.20 \%$ at days 14 and 28 , respectively (Tables 2 and 3).

\begin{tabular}{|c|c|c|c|c|c|c|c|}
\hline Group & Treatment & Dose (mg/kg) & Day 0 & Day 14 & Day 28 & $\begin{array}{l}\text { Change (\%) (Day } \\
\text { 14) }\end{array}$ & $\begin{array}{l}\text { Change (\%) (Day } \\
\text { 28) }\end{array}$ \\
\hline A & SME & 100 & $22.70 \pm 5.08$ & $30.52 \pm 2.99$ & $19.36 \pm 3.48$ & -34.40 & 14.70 \\
\hline B & - & 200 & $27.69 \pm 2.72$ & $31.09 \pm 5.89$ & $19.40 \pm 4.19$ & -12.30 & 29.90 \\
\hline C & - & 400 & $29.26 \pm 3.97$ & $33.98 \pm 6.19$ & $18.67 \pm 1.65$ & -16.10 & 36.20 \\
\hline D & Solvent & - & $35.42 \pm 4.65$ & $30.13 \pm 0.78$ & $18.68 \pm 6.89$ & 14.90 & 47.30 \\
\hline
\end{tabular}

Values are mean \pm SEM, $n=5$ per group; $p<0.05$ compared with control and day values respectively (One-Way Anova; Duncan test post hoc). SME- Stemonocoleus micranthus extract, solvent- distilled water. Change (\%) calculated relative to day 0 values.

Table 3: Effect of SME on serum LDL-cholesterol concentration.

The result also showed that the serum concentrations of TAG and VLDL did not differ significantly ( $\mathrm{p}>0.05)$ on day 14 post treatment as compared with the control and baseline values, respectively. However, on day 28 post treatment, SME $(100,200$ and $400 \mathrm{mg} / \mathrm{kg})$ was found to significantly $(\mathrm{p}<0.05)$ reduce serum concentrations of TAG and VLDL compared to baseline values. The percentage change in TAG was 17.70 $46.20,30.70 \%$ and $57.60,61.40,62.60 \%$ while VLDL was $18.30,54.50$, $31.10 \%$ and $60.20,67.30,62.80 \%$ at days 14 and 28 respectively (Tables 4 and 5).

\begin{tabular}{|c|c|c|c|c|c|c|c|}
\hline Group & Treatment & $\begin{array}{l}\text { Dose } \\
\text { (mg/kg) }\end{array}$ & Day 0 & Day 14 & Day 28 & $\begin{array}{l}\text { Change (\%) (Day } \\
14)\end{array}$ & $\begin{array}{l}\text { Change (\%) (Day } \\
\text { 28) }\end{array}$ \\
\hline A & SME & 100 & $86.38 \pm 7.76$ & $71.11 \pm 7.10$ & $34.64 \pm 2.24^{\#}$ & 17.70 & 57.60 \\
\hline B & - & 200 & $101.80 \pm 16.97$ & $54.73 \pm 7.57$ & $39.33 \pm 3.46^{\#}$ & 46.20 & 61.40 \\
\hline C & - & 400 & $106.84 \pm 12.72$ & $74.07 \pm 16.51$ & $39.97 \pm 3.05^{\#}$ & 30.70 & 62.60 \\
\hline D & Solvent & - & $83.99 \pm 13.35$ & $68.19 \pm 3.03$ & $53.63 \pm 4.16$ & 18.80 & 36.10 \\
\hline
\end{tabular}

Values are mean \pm SEM, $n=5$ per group; * \#: $p<0.05$ compared with control and base line values respectively (One-Way Anova; Duncan test post hoc). SMEStemonocoleus micranthus extract, solvent- distilled water. Change (\%) calculated relative to day 0 values.

Table 4: Effect of SME on serum triacylglycerol concentration.

The result showed that the extract at the different doses administered reduced the lipid profile markers (total cholesterol, triacylglycerol, LDL, VLDL) with concomitant increase in the HDL cholesterol concentration. It is well known that alterations in serum lipid profiles contribute to development of coronary heart disease [21]. Therefore, a reduction in serum lipids, particularly LDL and VLDL fractions and triacylglycerol concentration should be considered as beneficial in maintaining the normal physiologic levels of these lipids thereby reducing the risk of dyslipidemia.
Moreover, it was suggested that HDL may play a protective role in atherogenesis by preventing the generation of an oxidative modified LDL. The mechanism of action of HDL may involve exchange of lipid peroxidation product between the lipoproteins [22] and its cardioprotective properties which is achieved by protecting LDL from oxidative modifications [23]. However, the mechanism by which Stemonocoleus micranthus extract exhibit its hypolipidemic role could be attributed to an increased cholesterol excretion and decreased cholesterol absorption through the gastro intestinal tract or as a result of rapid catabolism of LDL-cholesterol by the liver for final elimination 
Citation: Mbaoji F, Ezike A, Nworu C, Onyeto C, Obi B, et al. (2017) Sub-chronic Effect of Methanol-Dichloromethane Stem Bark Extract of Stemonocoleus micranthus Harms. (Fabaceae) on Lipid Profile and Histology of Liver and Kidney of Rats. J Pharmacogn Nat Prod 3: 138. doi: $10.4172 / 2472-0992.1000138$

Page 4 of 6

in form of bile acids [24]. The extract seemed to be more effective in reducing triacylglycerol, total cholesterol and VLDL; and increasing HDL than in reducing LDL in normoglycemic condition. Hyperlipidemia associated with lipid disorders are considered to cause atherosclerotic cardiovascular disease [25]. Interestingly, the plant extract may be highly beneficial in preventing the development of atherosclerotic plague formation considering its lipid lowering potentials especially in normal rats.

\begin{tabular}{|l|l|l|l|l|l|l|l|}
\hline Group & Treatment & Dose (mg/kg) & Day 0 & Day 14 & Day 28 & $\begin{array}{l}\text { Change (\%) } \\
\text { (D) }\end{array}$ & $\begin{array}{l}\text { Change (\%) (Day } \\
\text { 28) }\end{array}$ \\
\hline A & SME & 100 & $17.40 \pm 1.52$ & $14.22 \pm 1.51$ & $6.93 \pm 0.45^{\#}$ & 18.30 & 60.20 \\
\hline B & - & 200 & $24.03 \pm 2.83$ & $10.94 \pm 1.51$ & $7.86 \pm 0.69^{\#}$ & 54.50 & 67.30 \\
\hline C & - & 400 & $21.50 \pm 2.63$ & $14.81 \pm 3.30$ & $7.99 \pm 0.61^{\#}$ & 31.10 & 62.80 \\
\hline D & Solvent & - & $23.44 \pm 4.81$ & $13.64 \pm 0.61$ & $10.73 \pm 0.83$ & 41.80 & 54.20 \\
\hline
\end{tabular}

Values are mean \pm SEM, $n=5$ per group; *, \#: $p<0.05$ compared with control and base line values respectively (One-Way ANOVA; Duncan test post hoc). SME Stemonocoleus micranthus extract, solvent - distilled water. Change $(\%)$ calculated relative to day 0 values.

Table 5: Effect of SME on serum VLDL-cholesterol concentration.

\begin{tabular}{|c|c|}
\hline Constituents & Relative abundance of constituents \\
\hline Alkaloids & + \\
\hline Carbohydrates & ++++ \\
\hline Fats and oils & ++ \\
\hline Flavonoids & ++++ \\
\hline Glycosides & ++++ \\
\hline Proteins & +++ \\
\hline Reducing sugars & +++ \\
\hline Resins & - \\
\hline Saponin & ++ \\
\hline Steroids & ++ \\
\hline Tannins & ++++ \\
\hline Terpenoids & + \\
\hline
\end{tabular}

Table 6: Phytochemical analysis.

The phytochemical analysis on the plant extract revealed that the extract tested positive to alkaloids, carbohydrates, fats and oil, flavonoids, glycosides, proteins, reducing sugars (Table 6). It equally gave positive reaction for saponins, steroids, tannins, and terpenoids. Several reports have documented the antiatherosclerotic effects of phenolic compounds (such as flavonoids, terpenoids tannins and saponins [26,27]. It is most likely that the hypolipidemic effect of this plant stem bark extract may largely be due to combined effects of carbohydrates, flavonoids, glycosides, protein, reducing sugars and tannins or may be ascribed to a single constituent.

The microscopic examination revealed that there were no significant changes in morphological or pathological lesions in the kidney (Figure 1) and liver (Figure 2) tissues of rats treated with various doses of Stemonocoleus micranthus extract compared with the control group. The organs had normal cellular architecture even in animals that received higher doses of the extract, suggesting the safety of the extract at the tissue level. This could be attributed to its active principles being nephroprotective and hepatoprotective. 
Citation: Mbaoji F, Ezike A, Nworu C, Onyeto C, Obi B, et al. (2017) Sub-chronic Effect of Methanol-Dichloromethane Stem Bark Extract of Stemonocoleus micranthus Harms. (Fabaceae) on Lipid Profile and Histology of Liver and Kidney of Rats. J Pharmacogn Nat Prod 3: 138. doi: $10.4172 / 2472-0992.1000138$

Page 5 of 6

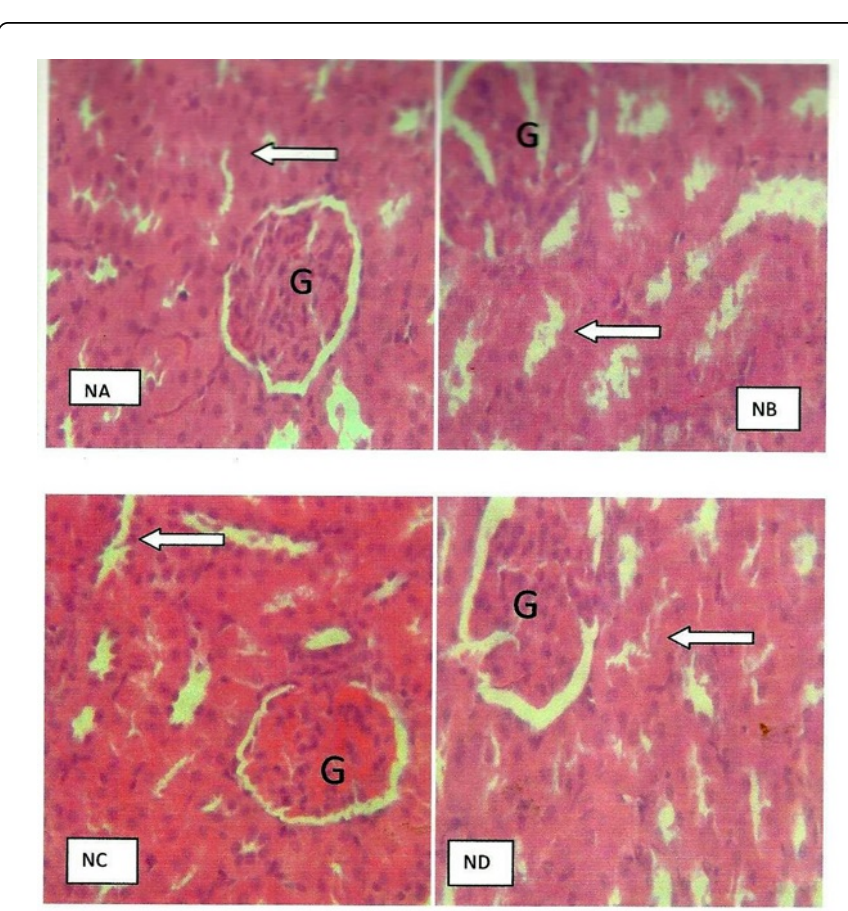

Figure 1: Histologic section of kidney from normoglycemic rats NA, $\mathrm{NB}, \mathrm{NC}$ and ND showing the glomerulus $(\mathrm{G})$ and renal tubules (arrows) with no observable changes. Key: NA=100 mg/kg, NB=200 $\mathrm{mg} / \mathrm{kg}, \mathrm{NC}=400 \mathrm{mg} / \mathrm{kg}, \mathrm{ND}=$ control (distilled water).
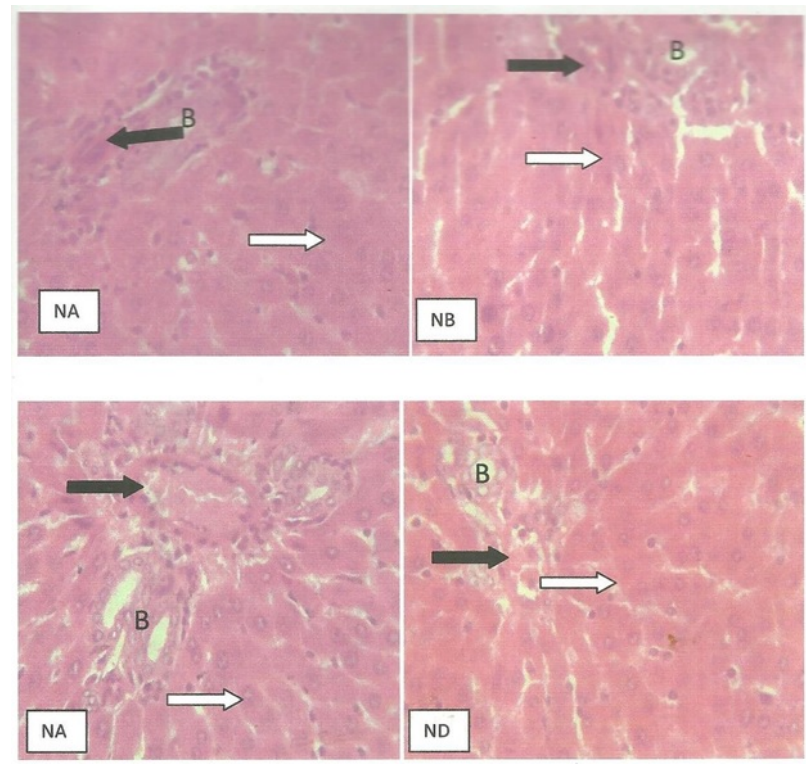

Figure 2: Histologic section of liver from normoglycemic rats NA, NB, NC and ND showing the portal area with bile ducts (B) and hepatic artery (black arrow), and apparently normal plates of hepatocytes (white arrows). Key: $\mathrm{NA}=100 \mathrm{mg} / \mathrm{kg}, \mathrm{NB}=200 \mathrm{mg} / \mathrm{kg}$, $\mathrm{NC}=400 \mathrm{mg} / \mathrm{kg}, \mathrm{ND}=$ solvent (distilled water).

\section{Conclusion}

The results of the present study have shown that the stem bark extract of Stemonocoleus micranthus possesses hypolipidemic activity in rats. This activity is largely attributed to the combined effects of constituents present in the extract. Further studies on the isolation and characterization of the active phytoconstituents are ongoing.

\section{Acknowledgements}

The authors wish to thank Mr. A Ozioko of InterCEDD for the plant collection and Dr. Onoja for his technical assistance.

\section{Authors Contribution}

All authors contributed equally in designing, performing the experiment and writing up of the research work. All authors read and approved the work.

\section{Conflict of Interest}

The authors have declared that no competing interests exist.

\section{References}

1. Breslow JL (1997) Cardiovascular disease burden increases, NIH funding decreases. Nature Med 3: 600-601.

2. Rother al, Collard cd (2001) Atherosclerosis and the genetic basis of lipoprotein disease. Best Pract Res Clin Anaesthesiol 15: 169-183.

3. Pokhrel B, Rijal S, Raut S, Subedi P, Magar RT (2015) Effects of crude extract of Ageratum conyzoides on serum lipid profile in albino mice and its haemostatic effects. Int J Plant Biol Res 3: 1047.

4. Law MR (1999) Lowering heart disease risk with cholesterol reduction: evidence from observational studies and clinical trials. Eur Heart J Suppl 1: S3-S8.

5. Shaten BJ, Kuller LH, Neaton JD, MRFIT Research Group (1991) Association between baseline risk factors, cigarette smoking, and CHD mortality after 10.5 years. Prev Med 20: 655-669.

6. Castelli WP, Anderson K, Wilson PW, Levy D (1992) Lipids and risk of coronary heart disease The Framingham Study. Ann Epidemiol 2: 23-28.

7. Waargovich MJ, Woods C, Hollis DM, Zander ME (2001) Herbals, cancer prevention and health. J Nutr 131: 3034S-3036S.

8. Lemmens RHMJ (2010) Stemonocoleus micranthus Harms. In: Lemmens RHMJ, Louppe D, Oteng AAA (Eds), PROTA (Plant Resources of Tropical Africa/Resources Vegetables de L' Afrique tropicale), Wageningen, Netherlands.

9. Anaga AO, Chah K, Tchimene MK, Udeani IC, Anaele N (2010) Investigation of the methanol extract of Stemonocoleus micranthus for pharmacological activities. NG J Exp Appl Biol 11: 97-107.

10. Keay RWJ (1989) Trees of Nigeria. Clarendon Press.

11. Ezea CC, Nnamdi-Okenwa CT, Ezugwu CO, Anowi FC, Ezea SC (2014) Investigation into the anti-ulcer activity of the methanol extract of Stemonocoleus micranthus Harms, bark (fam: leguminoseae). World J Pharm Res 3: 3669-3675.

12. Mbaoji FN, Ezike AC, Nworu CS, Onyeto CA, Nwabunike IA (2016 )Antioxidant and hepatoprotective potentials of Stemonocoleus micranthus stem bark Harms (Fabaceae) extract. Int J Phar and Pharmaceut Sci 8: 47-51.

13. Richardson PM, Harborne JB (1990) Phytochemical Methods: A Guide to Modern Techniques of Plant Analysis. Second Edition. Brittonia 42: 115.

14. Trease GE, Evans WC, Test book of Pharmacognosy, 11th ed. Brailliare Tindall and Macmillian Publishers, London. 1989: 176-180.

15. Allain CC, Poon LS, Chan CS, Richmond W, Fu PC (1974) Enzymatic determination of total cholesterol. Clin Chem 20: 470-475. 
Citation: Mbaoji F, Ezike A, Nworu C, Onyeto C, Obi B, et al. (2017) Sub-chronic Effect of Methanol-Dichloromethane Stem Bark Extract of Stemonocoleus micranthus Harms. (Fabaceae) on Lipid Profile and Histology of Liver and Kidney of Rats. J Pharmacogn Nat Prod 3: 138. doi: $10.4172 / 2472-0992.1000138$

Page 6 of 6

16. Albers JJ, Warnick GR, Cheung MC (1978) Quantification of high density lipoproteins. Lipids 13: 926-932.

17. Assman G, Jab HU, Hohnert U(1984) LDL-cholesterol determination in blood following precipitation of LDL with polyvinyl sulfate. Clin Chim Acta 140: 77-83.

18. Jacobs NJ, Van Denmark PJ (1960) Enzymatic determination of serum triglyceride Arch. Biochemistry. Bioph 88: 250-255.

19. Kono S, Shinchi K, Ikeda N, Yanai F, Imanishi K (1992) Green tea consumption and serum lipid profiles: a cross-sectional study in northern Kyushu, Japan. Prev Med 21: 526-531.

20. Devi R, Sharma DK (2004) Hypolipidemic effect of different extracts of Clerodendron colebrookianum Walp in normal and high-fat diet fed rats. J Ethnopharmacol 90: 63-68.

21. Laakso M (1996) Lipids and Lipoproteins as risk factors for coronary heart disease in non- insulin dependent diabetes mellitus. Ann Med 28 341-345.
22. Parthasarathy S, Barnett J, Fong LG (1990) High-density lipoprotein inhibits the oxidative modification of low density lipoprotein. Biochem Biophys Acta 1044: 275-285.

23. Nofer JR, Kehrel B, Fobker M, Levkau B, Assmann G (2002) HDL and arteriosclerosis: beyond reverse cholesterol transport. Atherosclerosis 161: 1-16.

24. Khanna AK, Rizvi F, Chander R (2002) Lipid lowering activity of Phyllanthus niruri in hyperlipidemic rats. J Ethnopharmacol 82: 19-22.

25. Nelson RH (2013) Hyperlipidemia as a risk factor for cardiovascular disease. Prim Care 40: 195-211.

26. Decker EA (1995) The role of phenolics, conjugated linoleic acid, carnosine, and pyrroloquinoline quinone as nonessential dietary antioxidants. Nutr Rev 53: 49-56.

27. Al-Fartosy AJM, Zearah SA, Alwan NA (2013) Total antioxidant capacity and antihyperlipidemic activity of alkaloid extract from aerial part of Anethum graveolens L. plant Eur Sci J 9: 413-423. 